\title{
Government Expenditure on Economic Growth: Empirical Evidence from Ghana
}

\author{
Charlotte Adamkie Atteh ${ }^{1}$, Joshua Akanyonge ${ }^{2 *}$, Alfred Asapeo ${ }^{3}$ \\ ${ }^{1}$ Department of Management, Regent University College of Science and Technology, Accra, \\ Ghana \\ ${ }^{2}$ Department of Accounting \& Finance, Regent University College of Science and \\ Technology, Accra, Ghana \\ ${ }^{3}$ Department of Library Services, C.K. Tedam University of Technology, Navrongo, Ghana
}

\begin{abstract}
The role of the government in a market economy cannot be underestimated. In reality, the public sector plays significant role in an economy. Markets do fail sometimes, and for that reason, government intervention is needed to provide public goods or handle externalities and enforce competition in an economy. In the quest of government playing its role in an economy, it faces the challenge of an appropriate level of government size (government final consumption \% of GDP) that can ensure sustained economic growth. Data on government fiscal behavior in Ghana over the last two decades generally shows a rising trend in government expenditure, yet the economic growth rate has not risen commensurately. The study set out to provide additional empirical evidence on the linkage between government size and economic growth in Ghana by a time series data analysis and to test the optimal threshold level of which government final consumption could lead to rapid growth in Ghana. The study concluded that total government expenditure has a direct positive impact on economic growth. As a result of that, the study recommended that government expenditure should not exceed the optimum threshold level of $0.114 \%$ to maximize economic growth. The study, therefore, advocates for fiscal discipline and control to keep government spending at the optimal level so as to trigger a positive ripple effect to other sectors of the economy and avoid a crowding out effect in the Ghanaian economy.
\end{abstract}

Keywords: Economic growth, Expenditure, Fiscal discipline, Government Size.

\section{Introduction}

The role of the government in a market economy cannot be underestimated. In reality, the public sector plays significant role in an economy. First of all, markets do fail sometimes, and for that reason, government intervention is needed to provide public goods or handle externalities and enforce competition in an economy. The scope and role of government have been accepted by society in a broader sense. Meanwhile, in Ghana, government activities have a powerful effect on the economy in areas like stabilization and growth; consumers and producers make most decisions that mold the economy based on government policy signals.

In recent times, there has been a public outcry in Ghana against the number of ministers government appoints. The public refers to the number of ministers as the size of government, which could affect government expenditure and slow growth. While obviously, the size of government does not refer to the number of ministers a government appoints, the public 
outcry is legitimate when considered in the context of the acknowledgement in literature and practical experiences that government expenditure levels clearly affect the rate of economic growth.

The public outcry also indicates that the level of government expenditure and rate of growth of the economy are important concerns for the public. Yet, knowledge on how public expenditure affects growth is scanty in the Ghanaian case, which calls for studies such as the present research.

Ghana, as a mixed economy, has a distinct nature of government involvement. The size of the public sector alone is a justification for the study of how it should best choose its means of revenue collection and its allocation of expenditure. Secondly, in determining the fair and efficient distribution of economic resources, the government is faced with the challenge of size. Over the years, several models have been developed to explain the public sector growth.

An example is Wagner's law. Hence this study investigates the linkage between government size and economic growth in Ghana. To achieve this goal and objective, the paper is specifically designed to: analyze the trends in government size and economic growth in Ghana, estimate the linkages between government expenditure and economic growth in Ghana, examine the optimal threshold level of government expenditure on economic growth.

The present study is organized in five sections. The rest of the study is structured as follows. Section II presents the theoretical and empirical literature review on the effect of growth in government spending. Research methodology (model specification, empirical strategy, and data issues) is discussed in Section III. Section IV deals with data analysis and interpretation of results, and Section V concludes the study with the summary of major findings and policy recommendations of the study.

\section{Related Work \\ Real GDP Growth (Economic Growth)}

The concept of economic growth was formulated and established in the early modern period when the western European nationals discovered that economies could produce a greater economic surplus which could, in turn, be spent on other aspects of the economy. According to scholars, the act of spending the surplus on projects which had a direct impact on the nationals as well as improving their livelihood could lead to the generation of more income for the country [1].

Mankiw [2] asserts that the term economic growth is used to indicate the increase of per capita gross domestic product or any other measure of aggregate income. It is either positive or negative depending on the quantity of goods and services which are produced. Generally, when a country post increased gross domestic product, economists relate that increase to improved standards of living. Minimal increase of the annual growth rate of any country's economy is fundamental in increasing the gross domestic product of the country, especially where the monetary policies are favourable for business.

\section{Theoretical Review}

Several theories have been used to explain the concept of economic growth and Government expenditure and its implications on the economy. However, none of the theories has been able to provide all answers to all the possible questions concerning economic growth-Government expenditure. For many years economist have been discussing the causes of growth and development and its association with Government expenditure. Here are some of the main lines of thought. The main theories relating to this study will be discussed.

\section{The Classical Growth Theory}

Classical economics is widely regarded as the first modern school of economic thought. Its major developers include Adam Smith, David 
Ricardo, Thomas Malthus, and John Stuart Mills [3]. Adam Smith and Malthus stressed the critical role of land in Economic growth. Adam Smith in explaining economic growth, began with a hypothetical idyllic age: 'that original state of things, which precedes both the appropriation of land and the accumulation of (capital) stock. This was, however, expressed at the time land was freely available to all and before capital accumulation had begun to matter. In the era of Adam Smith, because the land was freely available, people simply spread out onto more acres as population increases, just as settlers did in the American West. Because there was no capital, national output exactly doubles as population doubles. In this sense, wages earn the entire national income because there is no subtraction for land rent or interest on capital. Therefore, output expands in step with population, so the real wage per worker is constant over time.

This trend cannot continue forever because over time, as population growth continues, all the land will be occupied. Once this happens, balanced growth of land, labour, and output is no longer possible, resulting in new labour crowding onto already worked soils. The land, therefore, becomes scarce, and rents rise to ration it among different users.

As the population continues to grow, the national product also grows. But output must also grow more slowly than does population. This is because with new laborers added to fixed land, each worker now has less land to work with, and the law of diminishing returns comes into operation.

The increasing labour-land ratio leads to a declining marginal product of labour and hence to declining real wage rates. Malthus reasoned that population pressures would drive the economy to a point where workers were at a minimum level of subsistence. This implies that, whenever wages were above the subsistence, the population would expand; below-subsistence wages would lead to high mortality and population decline. Only at subsistence wages could there be a stable equilibrium of population [3]

According to Thomas Malthus, in the late eighteenth and early nineteenth century, growth in a country's output resulting from advances in technology is only temporary. Followers of this theory of growth argued that an increase in the real GDP per worker raises the subsistence level of wages per worker. This, in turn, will result in a population explosion and an increase in the available supply of labour. A greater supply of labour will depress the real wage, returning income per worker back to the subsistence level. The outcome is a fall in the rate of economic growth and an inevitable fall in the population itself at this subsistence level of income. The theory further indicates that, increase in the average real wage per worker to well above the subsistence level results in a population explosion. This implies that economic prosperity leads to more births and longer life expectancy. However, as the population grows, both capital per worker and output per worker fall, resulting in a fall in real wages per worker back to the subsistence level, and the population fall as a consequence, in line with falling living standards [4].

\section{The Neoclassical Growth Theory}

The classical theory led by Adam Smith and, in particular, Malthus did not recognize that technological innovation and capital investment could overcome the land of diminishing returns. Land did not become the limiting factor in production. Instead, the industrial revolution brought forth power-driven machinery that increased production, factories that gathered teams of workers into giant firms, railroads and steamships that link together the far points of the world, and iron and steel that made possible stronger machines and faster locomotives.

According to Solow, [5] the "neo-classical" model of growth was first devised by Nobel Prize-winning Economist Robert Solow over 40 years ago. The Solow model believes that a sustained increase in capital investment 
increases the growth rate only temporarily. This theory describes an economy in which a single homogeneous output is produced by two types of inputs, capital, and labour. In contrast to the Malthusian analysis, labour growth is determined by forces outside the economy and is unaffected by economic variables. In addition, they assume that the economy is competitive and always operates at full employment, so we can analyse the growth of potential output. This model emphasizes the importance of capital and technology change in economic growth.

For instance, if technology is held constant, then capital would be the focus of the growth process. Capital consists of durable produced goods that are used to make other goods. Capital goods include structures such as factories and houses, equipment like computers and machine tools, and inventories of finished goods and goods in process.

In the Economic growth process, economists stress the need for capital deepening, which is the process by which the quantity of capital per worker increases over time. Examples of capital deepening include the multiplication of farm machinery and irrigation systems in farming, of railroads and highways in transportation, and of computers and communication systems in banking. In each of these industries, societies have invested heavily in capital goods, increasing the amount of capital per worker. As a result, the output per worker has grown enormously in farming, transportation, and banking.

Further, this model asserts that, for a given state of technology, a rapid rate of investment in plant and equipment tends to depress the rate of return on capital. This occurs because the most worthwhile investment projects get constructed first, after which later investments become less and less valuable. Differences in the rate of technological change between countries are said to explain much of the variation in growth rates that we see. The neoclassical model treats productivity improvements as an 'exogenous' variable, meaning that productivity improvements are assumed to be independent of the amount of capital investment.

\section{Wagner's law}

There are two schools of thought called Wagner's law, named after the nineteenthcentury German Professor Adolf Wagner, and the other one the Keynesian views, which were suggested by the 20th-century British economist John Maynard Keynes. For Wagner's law, Sinha [6] reported that "Adolf Wagner was probably the first scholar to recognize a positive correlation between economic growth and the growth of government activity". In addition, Henrekson [7] pointed out from Wagner's law three main reasons for the increase in the government's role.

First, Industrialization and modernization would lead to a substitution of public for private activities and result in increasing government expenditures on law and order as well as on contractual enforcement. Secondly, an increase in real income would lead to an expansion of the income elastic "cultural and welfare" expenditures. Wagner cited two areas which are education and culture, in which the government could be a better provider than the private sector.

Thirdly, natural monopolies such as railroads had to be taken over by the government because the running cost of such kinds of activities are too expensive, and the private sector would be unable to obtain such huge investment to finance the development of these activities. In addition, he suggests that the private sector would also be unable to operate these activities efficiently. A study [8] concludes that Wagner's law is 'the law of expanding state activity, which in modern terminology posits that citizens' demand for government-provided goods and services is income-elastic, due to the "pressure for social progress" and the need for infrastructure investments. In a simple way, 
Wagner's law is interpreted as to say that government expenditure is a consequence of a growing economy.

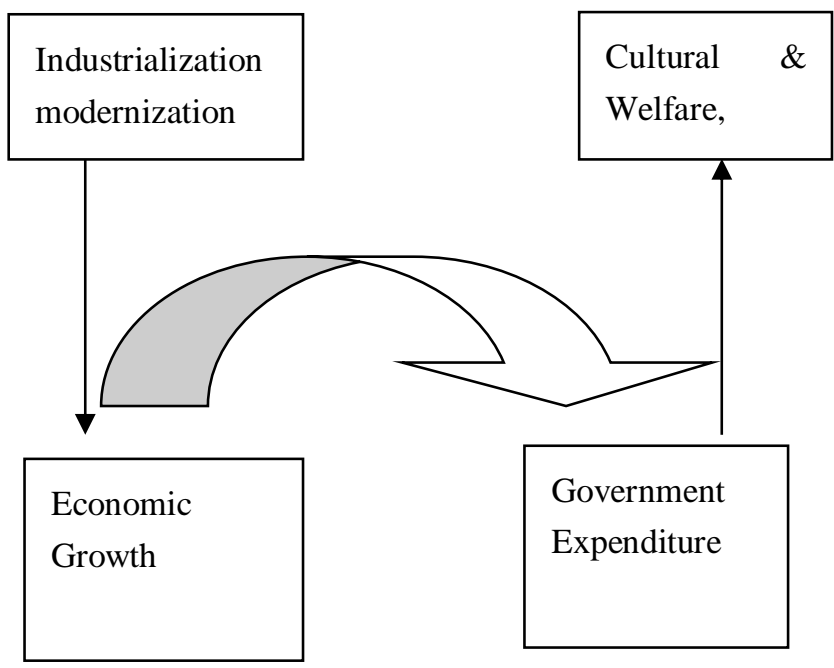

Figure 1. The circular flow of Wagner's law (drawn by author)

Source: Henrekson (1993)

On the other hand, the other economic interpretation for government expenditure and growth is explained by the Keynesian view. This view suggests that government expenditure contributes positively to economic growth through the multiplier effect on aggregate output; a high level of government consumption is likely to increase employment, profitability, and private investment. Branson [9] states that government expenditure raises aggregate demand that will lead to an increase in output. However, this situation depends on the multiplier effect, which in this case is the expenditure multiplier.

Therefore, it is very important to understand what actually the make-up of the expenditure multiplier is. Hence, several steps as shown below, are required in order to identify the expenditure multiplier. Furthermore, based on the Keynesian framework,

The comparison between increasing government expenditure with the reduction in tax is to show how tax cut can promote more private investment for economic growth. At the same time, the government expenditure through its activities can promote economic growth through other economic activities such as by creating more employment. The rule of thumb for this condition is that both activities should complement, instead of competing with, each other for economic growth. This rule is to avoid the argument on crowding-out effect theory. By complying to this rule, the function of the government expenditure can be through government activities such as providing education, healthcare, infrastructure development, defense, social security, judiciary, regulating externalities, pleasure marketplace, and others which complement the private sector and support the whole system for economic growth.

As a result, it will ensure a stable environment which will motivate investment in hopes of higher returns. Thus, for the Keynesian views, the circular flow can be drawn as below. 

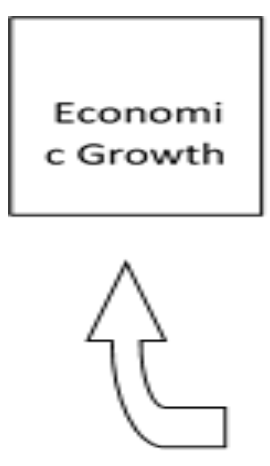
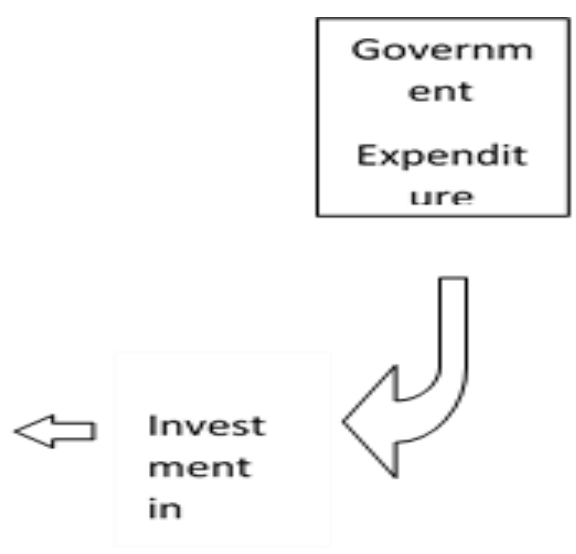

Figure 2. The Circular Flow of Keynesian Views (drawn by Author)

\section{Empirical Review}

In seeking to raise the well-being of its citizens, every government strives for growth. Yet, the relationship between the nature of government itself, specifically government spending, and economic growth is not an easy one. In this present research, the focus on this linkage between governments and economic growth is justified because, as Afonso and Jalles [10] succinctly put it, governments typically spend a sizeable share of society's resources and, therefore, they affect economic growth. It is also widely recognized that government plays a crucial role in the economy, including the provision of justice, health, education, defense, utilities, and physical infrastructure, among others. To this end, for its objective of examining this crucial linkage between government and growth, this present project draws from several other similar studies which explored this linkage from quite different angles.

In the literature, the size of government is conceived of as a level of government spending or expenditure, which is measured as a proportion of the Gross Domestic Product (GDP) of an economy [11]. Though the linkage between government size and economic growth is an important challenge, there is inconclusive evidence from several studies on these issues for any general theory to be formulated. While some works find that the level of government spending positively affects growth [13-15], others have found a negative relationship [10]; [16]. The present paper does not seek to support either side of these studies, but rather to draw lessons from them to investigate what effect public fiscal decisions and habits in Ghana, within the country's peculiar socioeconomic and political conditions, have had on the country's economic growth and development over the period 1992 to 2016.

Notwithstanding the mixed results of the studies on the relationship between government size and economic development, a number of works on this relationship reveal interesting dimensions. In Asimakopoulos and Karavias [11], there is an inverted U-shaped non-linear relationship between government spending and growth. The authors explain that increases in government spending have consistent positive effects on growth up to a certain threshold level, beyond which increases in spending begin to pose negative effects on growth. In this sense, the authors propose that the identification of the optimal level of government size to promote growth, which they found is around $20 \%$ of GDP, is the necessary big question to be addressed by academics, politicians, and bureaucrats. In this respect, it will be informative to find out the trend of Ghana's government expenditure relative to GDP and consequent growth patterns. Of course, it is acknowledged that other factors besides government spending may have affected the growth pattern of the Ghanaian economy, but 
such factors can be held constant in this present thesis.

Generally, positive, and negative effects of government spending on growth have been found along the developing/developed country divide as well as along quantity (size of government) and quality (institutional efficiency) lines. The literature is agreed that consistent increases in government expenditure result in expansionary impacts on the economy, most especially in developing countries. Countries with smaller economies tend to have large prospects for growth, such as in developing countries, and they tend to experience positive effects of increases in government spending on economic, all other things held constant, growth as compared to developed countries [11]. Similarly, smaller countries tend to expend bigger shares of their GDP on areas that are likely to be more directly productive [17]. Characteristic of developing countries, the negative effects of government spending on growth is attributed to government inefficiencies, crowding-out effects of government fiscal policies such as high taxation and domestic borrowing, the excess burden of taxation, financing of government spending through excessive borrowing and/or printing money $[10,11]$.

Not far from the developing/developed country divide in research results, Oto-Peralías and Romero-Ávil [18] make an interesting contribution. Directing attention from government size to government quality, they point out that government quality in terms of an efficient public sector is equally a significant factor that controls or mediates the effect of government spending on growth. By focusing specifically on public sector quality, which they conceptualize as characteristics and designs of public sector institutions, the authors also show that the linkage between government spending and growth is non-linear and varies with the quality of the public sector. Their findings are that government size negatively affects economic growth only when public sector quality (that is, institutional efficiency) is low. In other words, increases in government size either positively affect growth or is neutral when public sector institutions are highly efficient and working to satisfaction. In economies where institutions are weak or inefficient, corruption, rent-seeking, dishonesty, and abuse of power are rampant, and these work against the positive contribution of government spending to economic growth and development [18]. Such finding is consistent with remarks in Sheehey [19] and Afonso and Jalles [10] that the institutional contexts of government highly influence whether government spending positively or negatively affects growth.

Garey Durden and Barry Elledge studied the phenomenon at state, regional, and local levels of economy, still with mixed results at all these levels [20]. What this tells us is that regional data and not necessarily only national data can be used to estimate the relationship between government spending and growth. Their finding seems to confirm the earlier conclusion of Meltzer, and Richard [21] that the increased relative size of government appears to be independent of government at federal or national levels, budget and tax systems, and institutional arrangements, among others. These findings should, however, not be confused with saying that increases or changes in government spending is independent of these factors since it is conclusive that the relative rates of change in government spending will affect growth in different countries depending on the interplay of these factors.

From the general develop/developing country as well as quantity (size) and quality (institutional efficiency) line of analyses, pointers can be drawn to the critical contribution studies such as this present thesis can make to knowledge on the linkage between government size and government quality and economic growth. If developing country characteristics of small but growing economies, often being corruption, rent-seeking, excess 
taxation, and high borrowing, significantly mediate the ability of government spending to positively affect growth and development, it is imperative that a developing country such as Ghana pays high priority attention to addressing fiscal and institutional issues.

As Oto-Peralías and Romero-Ávila [18] conclude in their study, institutional context matters, and thus, this present research aims to contribute to efforts at understanding and to improve public sector institutions and government expenditure patterns so as to promote consistent growth.

\section{Methodology}

\section{Theoretical Framework}

The theoretical model underpinning my study is the neoclassical production function as follows,

$$
Y=f(K, L, A) \ldots \ldots(3.1)
$$

Where $\mathrm{Y}$ means economic growth, $\mathrm{K}$ represents Capital, L as Labour and $\mathrm{Y}$ as the output level, and A an index for the state of technology.

Scientific advances and technological change are key to the economic performance and social well-being of a nation. Government spends on intangible assets such as education, fundamental research in innovation, science, and technology, which leads to technological advancement for economic growth and social well-being. Education is important, as new technologies require skilled workers. Education stimulates more efficient ways of production organization as well as new and improved products and services. There is thus the possibility of sustained increases in investment which can lead to continuous rises in a country's growth rate. Knowledge can also spill over from one firm or industry to another, across borders, among universities, and from universities to businesses with new ideas used repeatedly at little extra cost. Such spillovers can ease the constraints placed on growth by the scarcity of capital.
Investment in technological transfer to improve health care has a profound effect in population growth rates. Better health care means more babies live to reproduce, and these people live to form the labour force of the economy and eventually get educated to bring about growth.

$A=g(G E$, Trade, inflation, population growth $)$

$$
\text { .. (3.1.1) }
$$

$$
\begin{gathered}
Y=f\{K, L, g(G E, \text { Trade, } \text { inflation }) \ldots . . .(3.1 .2) \\
Y=f(K, L, G E, \text { Trade, inflation }) \ldots . .(3.1 .3)
\end{gathered}
$$

We assume a Cobb- Douglas function,

$$
Y=\beta K t \alpha L t 1-\alpha G E t \gamma T t \theta I N F t \mu \text { e } \varepsilon t . . .(3.1 .4)
$$

$\mathrm{Y}$ is the real GDP growth rate, GE represents general government final consumption, $\mathrm{T}$ represents trade openness, INF represents inflation GDP deflator.

A normality test was conducted, and the distribution of sample means across independent samples was not normal. Therefore, the data was transformed, and the technique used was logarithm.

$$
\begin{gathered}
\operatorname{In} Y T=\operatorname{In} \beta+\alpha \operatorname{In} K+(1-\alpha) \operatorname{In} L+ \\
\gamma \operatorname{In} G E+\theta \operatorname{In} T+\mu \operatorname{In} \operatorname{IN} F+\varepsilon t \ldots \ldots \ldots(3.1
\end{gathered}
$$

\section{Model Specification}

\section{Model 1}

We first modelled a linear regression to determine the unique relationship that exists between the predictors (i.e., capital formation, population growth, general government final consumption, trade openness, inflation) on the criterion (i.e., economic growth).

$$
\begin{gathered}
\operatorname{In} Y T=\operatorname{In} \beta+\alpha \operatorname{In} K+(1-\alpha) \operatorname{In} L+\gamma \operatorname{InGE} \\
+\theta \operatorname{In} T+\mu \operatorname{In} \operatorname{IN} F+\varepsilon t
\end{gathered}
$$

\section{Model 2}

Secondly, the study employed the model estimation by Asimakopoulos and Karavias [11], where growth annual percentage will serve as the dependent variable and as explanatory variables; general government final consumption expenditure as a share of output, inflation rate as GDP deflator, gross capital 
formation to capture the share of investment to output, openness to trade and population growth. Asimakopoulos and Karavias [11] used panel data, but this study will make use of time series data for the period of 37 years from the World Development Indicators (WDI), as reported by the World Bank, and we perform a dynamic threshold estimation to estimate the optimal level of government spending in Ghana.

Model 2 was specified as:

$$
\begin{gathered}
G D P t=C t+\beta 1 G E t I(G E t \leq \mu)+ \\
\beta 2 G E t I(G E t>\mu)+\mathrm{nXt}+\pi \mathrm{t}
\end{gathered}
$$

Where $\mathrm{Ct}$ is the constant term, and it measures the value of economic growth when all the explanatory variables are constant. $\pi \mathrm{t}$ it is the remainder error term. GE is the government final consumption expenditure as a share of GDP and serves as the threshold variable where the threshold is given by the parameter. I (.) is the indicator function which takes the value 1 when the argument in the parenthesis is true and 0 otherwise. The inflation, capital formation, openness to trade, government expenditure, and population growth variables are in the vector Xt. $\eta$ is the coefficient of the vector variable $\mathrm{Xt}$. The above model specification was chosen because it has the advantage which allowing for endogenous independent and endogenous threshold variables.

\section{Data source and Data Type}

Secondary data was sourced from the World Development Indicator (WDI). The study utilized time series data for a period of 37 years within the period of 1980 to 2016. The data comprised figures on economic growth, gross capital formation, inflation rates, Openness, and population growth for the period.

\section{Variable Description}

An independent variable is the presumed cause, whereas the dependent variable is the presumed effect. In this study, the dependent variable was economic growth, and the independent variable comprised of Government expenditure, capital formation, inflation rate, openness to trade, and population growth.

According to WDI (World Development Indicators) General government final consumption expenditure (formerly general government consumption) includes all current government expenditures for purchases of goods and services (including compensation of employees). It also includes most expenditure on national defence and security but excludes government military expenditures that are part of government capital formation. General government final consumption expenditure \% of GDP is used as a proxy to measure government size.

The annual percentage growth rate of GDP according to WDI was defined at market prices based on constant local currency. Aggregates are based on constant 2010 U.S. dollars. GDP is the sum of gross value added by all resident producers in the economy plus any product taxes and minus any subsidies not included in the value of the products. It is calculated without making deductions for depreciation of fabricated assets or for depletion and degradation of natural resources.

Gross Capital formation was used as a proxy to capture the share of investment to output. According to WDI (World Development Indicators), Gross capital formation (formerly gross domestic investment) consists of outlays on additions to the fixed assets of the economy plus net changes in the level of inventories. Fixed assets include land improvements (fences, ditches, drains, and so on); plant, machinery, and equipment purchases; and the construction of roads, railways, and the like, including schools, offices, hospitals, private residential dwellings, and commercial and industrial buildings. Inventories are stocks of goods held by firms to meet temporary or unexpected fluctuations in production or sales and "work in progress". According to the 1993 SNA, net acquisitions of valuables are also considered capital formation. 
According to WDI, Inflation, as measured by the annual growth rate of the GDP implicit deflator, shows the rate of price change in the economy as a whole. The GDP implicit deflator is the ratio of GDP in current local currency to GDP in constant local currency.

\section{Trade Openness}

According to WDI, Trade openness was calculated by adding imports and exports of goods and services as a share of gross domestic product.

\section{Population Growth}

WDI defined population growth as the Annual population growth rate for year $t$ is the exponential rate of growth of midyear population from year $\mathrm{t}-1$ to $\mathrm{t}$, expressed as a percentage. The population is based on the de facto definition of population, which counts all residents regardless of legal status or citizenship.

\section{Results and Discussion}

\section{Introduction}

The study focused on the linkage between Government expenditure ( $\%$ of GDP) and real GDP growth \% in Ghana. In addition, how other factors (inflation GDP deflator, gross capital formation \% of GDP, population growth $\%$, and openness to trade) influence economic growth in Ghana. Moreover, it presents the results of the estimated model in chapter three. The chapter is structured into regression results, results from hypothesis tested, explanation of model summary, statistical significance, and trend analysis for the government expenditure and economic growth in Ghana. Since all variables are either percentages or ratios to GDP, 1 was added before the $\log$ transformation.

\section{Trends Analysis in the Growth Rate of Government Expenditure and GDP Growth}

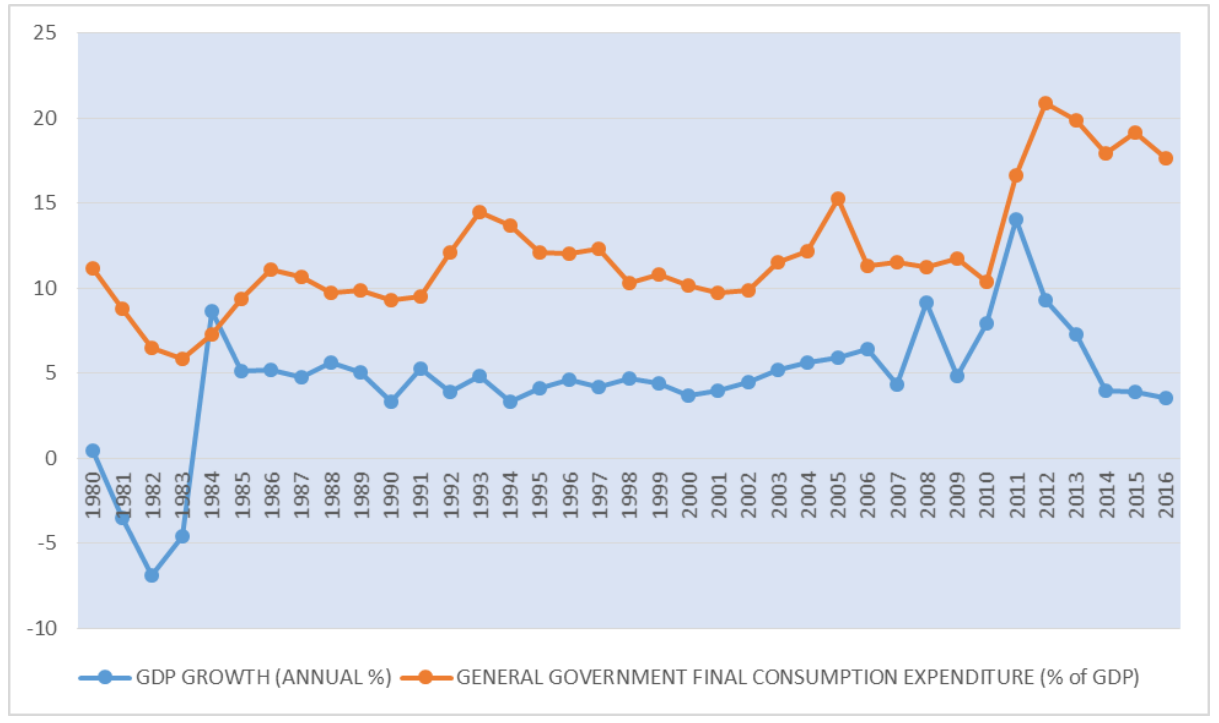

Figure 3. Trends in the Growth Rate of Government Expenditure and Real GDP Growth Rate

Source: World Development Indicator

Figure 1, according to the world development indicator, clearly shows that the rate of growth in government expenditure generally has a parallel influence on Gross Domestic Product (GDP) growth rate. A decline in government expenditure from about 1980 to around 1983 saw a corresponding decline in real GDP growth rate over roughly the same period. Subsequent significant rise in government expenditure around 1983-1984 saw a corresponding rise in growth rate, thereafter real GDP more or less maintaining a general 
steady rate even though government expenditure generally kept rising and falling marginally. The contention that government expenditure pulls real GDP along in a parallel direction is evident in fact, which is demonstrated in the movements of the curves in Figure 1 that along the year's government expenditure change occurs first before real GDP changes in a similar direction.

However, it is obvious from Figure 1 that a large government size (rising government expenditure) does not necessarily result in the growth or decline of the economy. Arguably, the generally steady rate of real GDP growth from about 1986 as against a generally marginal rise in government expenditure suggests that government expenditure affects growth, but there are intermediary factors that constrain or enhance the effect of government expenditure on growth. As is shown in the literature review below, possible factors include public sector institutional efficiency and structural challenges, especially in developing countries like Ghana.

The initiation of the Economic Recovery Program (ERP) and Structural Adjustment Program (SAP) by the Provisional National Defense Council (PNDC) government brought about an increase in government expenditure from 1984 to 1987. The ERP was aimed at promoting and boosting production. The government began to rebuild infrastructure through a facility of US\$ 4.2 billion programs, more than half of which was provided by external donors. Due to this, Ghana's real GDP registered a steady growth, most of which is attributable to the re-vamp of the export sector, including cocoa, minerals, and to some extent, timber processing.

As at the beginning of 1988 through to 1991 , after some slight decline in government expenditure in the preceding few years, the Government of Ghana had started investing into the economy again. The government initiated an eighty-five million Dollars (US\$ 85 million) Program of Action to Mitigate the Social Costs of Adjustment (PAMSCAD). The program sought to create 40,000 jobs over a two-year period and the rehabilitation and development of rural and urban social infrastructure throughout the country. The PAMSCAD program brought about growth in government expenditure, but for during this period, the growth rate of real GDP slowed down slightly.

Again by 1992 into 1994, Ghana had started experiencing about a five percentage points $(5 \%)$ increase in government expenditure. The government diversified some state-owned enterprises in 1990 and encouraged privatization throughout the country. This generated a lot of revenue for the government. As a result, the government invested back into the economy. Key priorities for 1992 were giving new impetus to state reforms, broadening the scope of banking-sector reforms, and liberalizing the administrative framework. Basic education and primary health care services were to receive attention over the long-term as well. However, was a corresponding marginal reduction in the rate of economic growth of about zero-point fifty-eight percent $(0.58 \%)$.

Circumstances subsequently changed significantly for the government. From 1995 to 1997, the government was not earning enough revenue and was being pressured by donor agencies to join the Highly Indebted Poor Country (HIPC) initiative since her indebtedness was high and growing. Government expenditure experienced about a two percent $(2 \%)$ reduction in its growth rate. Consequently, to salvage the economy the foregoing, the NPP government opted for the International Monetary Fund's (IMF) Highly Indebted Poor Country (HIPC) initiative in 2001, which run till 2008. The initiative led to a significant debt relief service to Ghana but after the program run to an end, the economy was stiffened and was faced with hardship since the government was not investing into capital projects due to the unwillingness of donor agencies to support the government's budget. 
Ghana was still signed on to the HIPC initiative from 2004 to 2008 . This was to enable the country to cancel even more of its debts owed the donor agencies such as the IMF. Thus, the growth rate of government expenditure moved up by about sixteen percent (16\%) in 2004 to 2008. As Ghana had entered the second face towards the completion point of the HIPC initiative, the Government of Ghana received a lot of debt relief from the IMF.

Moreover, getting to the end of 2008, the Ghanaian government sold its shares in the Ghana Telecom (GT) firm to Vodafone Ghana. Also, Ghana's new oil found at cape three points can be attributed to this change from state to private sector-led growth. There was an increase in the growth rate of government expenditure at about three percent (3\%).

In 2009, the introduction of the single spine salary structure gave the curve a higher slope. As the economy grows, the activities of the government increase, and more people will be hired to perform these tasks, which automatically raise the expenditure level.

As part of the policy, the then President of Ghana ensured no child was deprived of basic education from 2011, and this led to an intervention of supplying free school uniforms and 23 million free exercise books to pupils in deprived communities. The initiative used local fabrics and local textile industries in order to support the local textile industry as well as increase school enrolment. It contributed to a sharp increase in government expenditure and a corresponding increase in economic growth.

However, through 2011 to 2016, the shortage of power hobbled the growth of the economy and affected both business and residential customers. Many businesses had to resort to the use of generators to survive. According to Graphic Online (January 2017), statistics at the end of 2015 showed that in excess of 76 percent of both rural and urban residents have access to potable water. Moreover, massive investments in the construction of roads were much evident within the period of 2013 to 2016, leading to an increase in government expenditure. This shows that the trend between government expenditure and economic growth has not been consistent for the period.

\section{Regression Results}

Model 1 first modelled a linear regression to determine the unique relationship that exists between the predictors (i.e., gross capital formation, population growth annual $\%$, general government final consumption \% of GDP, trade openness, inflation GDP deflator) on the criterion (i.e., Real GDP Growth \%).

In addition, in Model 2, a threshold regression analysis was conducted to determine the non-linear relationship that exists between the key variable (general government final consumption \% of GDP) on Real GDP Growth $\%$ as well as gross capital formation \% of GDP as a proxy for investment, inflation GDP deflator $\%$ and population growth $\%$ and openness to trade. Also, the significance of the overall model using the F-statistic and variance was conducted. In addition, test of autocorrelation was conducted using the figure of the Durbin Watson test to determine the existence of autocorrelation.

A Summary of the linear regression and the non-linear regression result is presented in Table 1 below. Details of the results and data used for the analysis are presented in the appendix. 
Table 1. Results of Linear and Non-linear Threshold Estimations

\begin{tabular}{|c|c|c|c|c|}
\hline \multirow[t]{2}{*}{ Variables } & \multirow{2}{*}{$\begin{array}{l}\text { Linear regression } \\
\text { Model } 1\end{array}$} & \multirow[t]{2}{*}{ Std Error } & \multirow{2}{*}{\begin{tabular}{|l|} 
Non-Linear regression \\
Model 2
\end{tabular}} & \multirow[t]{2}{*}{ Std Error } \\
\hline & & & & \\
\hline LNGE $^{\mathrm{b}}$ & - & - & $1.071052 * * *$ & 0.345131 \\
\hline LNGE $^{\mathrm{a}}$ & - & - & $0.674953 * * *$ & 0.242275 \\
\hline LNGE & 0.139419 & 0.255671 & 0.1142886 & - \\
\hline LNK & 0.287462 & 0.239172 & $0.347651 * *$ & 0.153454 \\
\hline LNL & 2.897317 & 2.978015 & $6.392493 * *$ & 2.562086 \\
\hline LNT & -0.001090 & 0.080799 & -0.011005 & 0.049447 \\
\hline LNINF & -0.067865 & 0.042126 & $-0.080238^{* *}$ & 0.033339 \\
\hline CONSTANT & $0.921897 * * *$ & 0.105215 & $0.741751 * * *$ & 0.098296 \\
\hline $\mathrm{r}^{2}$ & 0.423333 & - & 0.530949 & - \\
\hline $\mathrm{aDJ} \mathrm{R}^{2}$ & 0.330322 & - & 0.437139 & - \\
\hline F-stat & 4.551442 & - & 5.659821 & - \\
\hline pROB(F-STAT) & 0.003156 & - & 0.000501 & - \\
\hline \multicolumn{5}{|c|}{ Source from Eviews (Compiled by author) } \\
\hline \multicolumn{5}{|c|}{ a. Dependent Variable: Real GDP Growth \% (LNGRGDP) } \\
\hline \multicolumn{5}{|c|}{$\begin{array}{l}\text { b. Independent Variables: Government Expenditure (\% GDP), gross capital formation (\% of } \\
\text { GDP), population growth (annual \%), trade openness, inflation GDP deflator. }\end{array}$} \\
\hline \multicolumn{5}{|c|}{ c. Threshold variable: Government Expenditure (\% GDP) } \\
\hline \multicolumn{5}{|c|}{ d. $* * *, * *$ indicates significance at $1 \%$ and $5 \%$ respectively. } \\
\hline \multicolumn{5}{|c|}{$\begin{array}{l}\text { e. The optimal threshold level below and above government expenditure as a percentage of } \\
\text { gdp respectively is LNGE }<0.1142886 \text { and } 0.1142886<=\text { LNGE }\end{array}$} \\
\hline
\end{tabular}

\section{Results from Hypothesis Tested}

All the hypotheses in the study were tested at $1 \%$ and $5 \%$ level of significance. Following from above, five variables were significant at $1 \%$ and $5 \%$ in both models.

Table 1 represents the results of the linear regression and the non-linear threshold regression estimation. The first, second, and fourth columns show the variables, coefficient of the independent linear regression variables, and the non-linear model coefficient. Lastly, columns three and five show the standard errors of the two models.

A Durbin Watson test results in the study found a figure of 1.41. This means that there is no positive serial or autocorrelation found between the independent variables in the study. It also means that the error term of the model was uncorrelated with the independent variables in the study.

\section{Model 1}

In the linear regression model, the constant term (0.921897) is the value of the dependent variable when all the independent variables and the error term is zero, but these values almost never equal zero. This is the intercept for the regression line. The constant term of the linear model was found to be significant at $1 \%$.

Moreover, the general government final consumption \% of GDP coefficient was 0.139419 , statistically not significant. That is, a $1 \%$ increase in general government final consumption leads to 0.13 dollars increase in real GDP growth (economic growth) and vice versa. This, however, confirms the expected relationship between general government final consumption and real GDP growth (economic growth). For gross capital formation, the results showed a positive and significant linkage on real GDP growth (economic growth). The coefficient of gross capital formation was 
statistically not significant at a coefficient of 0.287462 . Thus, a $1 \%$ increase in gross capital formation causes real GDP growth (economic growth) to increase by 0.28 dollars holding all other variables in the model constant.

A positive effect of population growth on real GDP growth (economic growth) was realized. Population growth was statistically not significant at a coefficient of 2. 897317. Thus, a $1 \%$ increase in population growth leads to 2.89 dollars increase on real GDP growth (economic growth), holding all other variables in the model constant.

Furthermore, the result from the interaction of trade on economic growth was negatively related. Trade was not significant at a coefficient of -0.001090 . Thus a $1 \%$ increase in trade openness leads to a 0.001 dollar decrease on real GDP growth (economic growth), holding all other variables in the model constant.

Lastly, the estimated coefficient of inflation 0.04 , decreases economic growth or real GDP growth by 0.04 dollars for every $1 \%$ increase in inflation, holding all other variables in the model constant.

The R2 of the model was 0.423 , which indicates that all the dependent variables, Government Expenditure (\% GDP), gross capital formation ( $\%$ of GDP), population growth (annual \%), trade openness, and inflation GDP deflator explains about $42 \%$ of the variations in real GDP growth (economic growth) in Ghana. This indicates that the variables fairly fit the model.

\section{Model 2}

According to Table 1, with respect to model 2 , the threshold variable is General government final consumption expenditure ( $\%$ of GDP). The optimal threshold level of government size is $1.301 \%$ of GDP. From the problem statement, the size of government is not necessarily the number of cabinet ministers. In this study, Government size was measured in terms of the volume of GDP that the economy can generate. For every $13 \%$ the government spends on appointed ministers, it should generate a corresponding $10 \mathrm{Ghc}$ of GDP. On individual countries, reports show that Zhu et al. [22]; Altunc and Aydin [23], and Chen and Lee [24] estimated a threshold within the range of $11-25 \%$ and Karras [25] in a sample of 20 European countries established an optimal level of government spending equal to $16 \%$.

Moreover, table 1 estimated the non-linear impact on real GDP growth (economic growth) when it is above and below the optimal level of government spending. Additionally, the coefficient of General government final consumption expenditure is positive and significant at $1 \%$ level for both above GE group $(\beta 2=0.67$; s.e. $=0.24)$ and below GE group $(\beta 1=1.07$; s.e. $=0.34)$. A $1 \%$ increase in government expenditure as a share of GDP will enhance economic growth approximately by $1 \%$ increase in government expenditure as a share of GDP will decrease growth by $0.67 \%$ when government size is above the threshold level at $1 \%$ significance level.

With regards to the non-threshold variables, which are gross capital formation (\% of GDP), population growth (annual \%), trade openness, and inflation GDP deflator, we find that inflation is negative and statistically not significant. The estimated coefficient of inflation -0.08 , decreases real GDP growth by 0.08 dollars for every $1 \%$ increase in inflation, holding all other variables in the model constant.

Gross Capital formation \%, which is a proxy for investment, was found to be positive and statistically significant at 5\% significance level within the period 1980 to 2016. As the estimated coefficient of the gross capital formation increases economic growth by 0.27 dollars for every $1 \%$ increase in capital formation, holding inflation, trade openness, and population growth constant. Moreover, the prediction for capital formation was supported. A Study [11] similarly reported a positive and a statistical significance for capital formation 
with respect to developed and non-developed counties.

Thirdly, a significant positive relationship between trade openness and economic growth was not supported. Trade openness revealed an insignificant negative linkage with economic growth. It statistically impacted on real GDP growth at 5\% level of significance. Thus, a $1 \%$ increase in trade openness causes real GDP growth to decrease by 0.01 dollars.

Also, we find that population growth positively and insignificantly relates to economic growth.

Lastly, the study displayed a direct impact between government expenditure and economic growth. Government expenditure significantly impacted on economic growth. It shows that economic growth will increase by will increase by $0.38 \%$ for every $1 \%$ increase in government expenditure holding constant inflation rate, gross capital formation, openness to trade, and population growth.

\section{Conclusion and Future Scope}

\section{Summary of Major Findings}

The study showed that government final consumption \% of GDP positively impacted on economic growth. It shows that economic growth will increase by $0.14 \%$ for every $1 \%$ increase in government final consumption $\%$ of GDP holding constant inflation rate, gross capital formation, and openness to trade and population growth.

We assessed the non-linear relationship between government size (using government final consumption \% of GDP as proxy) and real GDP growth under a sample of 37 time-series data set using a threshold regression model. We found that the optimal level of government size that maximizes economic growth is $0.114 \%$ of GDP. From table 1, a non-linear relationship between government final consumption $\%$ of GDP and economic growth is statistically significant at $1 \%$ level around the optimal level, the upward and downward slopping part of the curve.
Also, with regards to the non-threshold variables, which are inflation GDP deflator, gross capital formation, trade openness, and population growth, the study, observed that there was an insignificant negative relationship between inflation and economic growth. The estimated coefficient of inflation -0.08 , decreases economic growth by 0.08 for every $1 \%$ increase in inflation, holding constant all other variables in the model.

Further, the gross capital formation was found positive and statistically significant within the period 1980 to 2016. The estimated coefficient of gross capital formation is 0.34 . As the estimated coefficient of the capital formation increases economic growth by 0.34 for every $1 \%$ increase in gross capital formation, holding constant all other variables.

Again, trade openness revealed an insignificant negative linkage with economic growth. A $1 \%$ increase in trade openness, holding all variables constant, decreases economic growth by 0.011 . Lastly, we found that population growth positively and insignificantly relates to economic growth.

\section{Conclusion}

The study estimated the linkage between government size and economic growth using general government final consumption expenditure (\% of GDP) as a proxy to measure government size in Ghana for a time period of 1980 to 2016. Moreover, the optimal threshold level of government expenditure on economic growth was examined.

Findings showed that Government expenditure directly impacted on economic growth holding inflation rate, gross capital formation, openness to trade, and population growth constant. Even though government expenditure did not significantly predict growth rate, the expected positive direction predicted in the study was obtained.

A non-linear relationship between government size and economic growth under a sample of 37 time-series data set using a 
threshold regression model. We found that the optimal level of government size that maximizes economic growth is $1.301 \%$ of GDP. From Table 1, a non-linear relationship between government expenditure and economic growth is statistically significant around the optimal level, the upward and downward slopping part of the curve.

The data used for the estimation was not primary information collected by the researcher personally but rather was obtained from International Finance Statistics of the World Bank. Thus, the validity and reliability of the data cannot be substantiated in the study. This may have the tendency to affect the outcome of the study. In addition, a test of relationship might not necessarily mean there is causation. For instance, a significant positive relationship between government expenditure and economic growth might not mean that government expenditure caused economic growth. Finally, some of the data used are several years old, and this might not reflect the current market or growth conditions.

\section{Recommendations of the Study}

Based on the general findings indicated in the previous section, the study recommends the following for policy makers to act upon them:

1. Total government expenditure has a direct positive impact on economic growth. As a result of that the study recommends that government expenditure should not exceed the optimum threshold level of $0.114 \%$ of GDP to maximize real GDP growth (economic growth).

2. Moreover, government consumption spending should be well coordinated by all arms of government to prevent the "crowd out" effect on government investment. There should be a high degree of transparency and accountability on government spending at various sectors of the economy in order to prevent the channeling of public funds to private accounts of government officials.

3. In addition, Government should monitor contracts awarding processes of projects closely to prevent against overestimation of execution cost. This will bring about a significant impact of public investment spending on economic growth.

4. Among many roles, the Bank of Ghana is expected to stabilize the inflation rate at a level supportive of sustainable economic growth. A single-digit and stable inflation is needed to minimize instabilities and uncertainties in the domestic financial market, and this will automatically lend enormous support to capital formation needed for investment in Ghana.

5. Lastly, an economy that specializes in the production of a particular good in which it has a comparative advantage in realizes sufficient economic growth as compared to producing everything. The study proposes that trade with the neighboring countries and the global world should be encouraged. National culture should be instilled in the citizens of Ghana to patronize in domestically manufactured products while a national policy is put in place to encourage the export of processed products. This will guarantee the country favorable terms of trade which is needed to repair the country's trading position.

\section{Acknowledgement}

Since no organization sponsored this work, no acknowledgment is made.

\section{Conflict of Interest}

The author declares that there is no conflict of interest. 


\section{References}

[1] Heijdra, J.B. and Ploeg, V.D., 2002, The foundations of modern macroeconomics: Oxford University Press, USA.

[2] Mankiw, G., 2007, The role of economic growth in macroeconomics: MIT Press.

[3] Heinz, D. And Kurz, C.L., 2000, Input-output Analysis and Classical Economic Theory. Economic Systems Research, 12(2): 139-140.

[4] Nellis, J.G., and Parker, D., 2004, Principles of Economics, ( $1^{\text {st }}$ ed.): Pearson Education LimitedEngland.

[5] Solow, Robert M., 1956, "A contribution to the theory of Economic Growth". Quarterly Journal of Economics, Vol. LXX.

[6] Sinha, D., 1998, Government Expenditure and Economic Growth in Malaysia. Journal of Economic Development, Vol. 23, Number 2, pp. 71-80.

[7] Henrekson, M., 1993, Wagner's Law - a Spurious relationship. Public Finance, 48, pp. 406415.

[8] Slemrod, J., Gale, W. and Easterly, W.,1995, What do Cross-Country Studies Teach about Government Involvement, Prosperity, and Economic Growth, Brooking Papers on Economic Activity, (2), pp. 373-431.

[9] Branson, W. H. 1989, Macroeconomic Theory and Policy, 3rd ed., New York: Harper \& Row.

[10] Afonso, A. and Jalles, J. T. 2011, Economic performance, and government size. Working Paper Series 1399 / November 2011. European Central Bank, 2011, Frankfurt.

[11] Asimakopoulos, S. and Y. Karavias, 2015, The impact of government size on economic growth: A threshold analysis (2015), Economics Letters, http://dx.doi.org/10.1016/j.econlet.2015.12.010.

[12]Caselli, F., Esquivel, G., and Lefort, F.,1996, Reopening the convergence debate: A new look at cross-country growth empirics, Journal of Economic Growth 1(3): 363-389.

[13]Romero-Ávila, D., and R. Strauch (2008). Public finances and long-term growth in Europe: Evidence from a panel data analysis, European Journal of Political Economy 24(1): 172-19.
[14]Bose, N., M. E. Haque, and D. R., Osborn (2007). Public expenditure and economic growth: A disaggregated analysis for developing countries, The Manchester School 75(5): 533-556.

[15] Guseh, J., 2007, Government size and economic growth in developing countries: A politicaleconomy framework. Journal of Macroeconomics 19(1): 175-192.

[16] Gray, C., T. Lane, and Varoudakis, A., 2007, Fiscal policy and growth in ECA: Lessons for Eastern Europe and Central Asia. Washington DC: The World Bank.

[17] Oto-Peralías, D. and Romero-Ávila, D., 2013, Tracing the link between government size and growth: The role of public sector quality. KYKLOS 66(2): 229-255.

[18] Sheehey, E.,1993, The effect of government size on economic growth. Eastern Economic Journal 19(3): 21-328.

[19]Durden, G. and Elledge, B. (n.d.), The effect of government size on economic growth: evidence from gross state product data. The Review of Regional Studies: 183-190.

[20] Meltzer, A. H., and Richard, S. F., 1981, A rational theory of the size of government. Journal of Political Economy. 89(5): 914-927.

[21]Zhu, Z, Chiou-Wei, S and Kuo, Y., 2010, Government size and economic growth: an application of the smooth transition regression model. Applied Economics Letters 17(14), 1405 1415.

[22] Altune, O.F., and Aydin, C, 2013, The relationship between the optimal size of government and economic growth: Empirical evidence from Turkey, Romania, and Bulgaria. Procedia-social and Behavorial sciences, 92, 66-75.

[23] Chen, S.T., and Lee, C.C, 200, Government size and economic growth in Taiwan: A threshold regression approach. Journal of policy modelling 27(9), 1051-1066.

[24] Karras (1997) Karras, B.E, 1999, Threshold effects in non-dynamic panels: estimation, testing, and inference. Journal of Econometrics, 93, 345-68. 